\title{
Encouraging junior doctors to work in rural Sudan: a discrete choice experiment
}

Nazik Nurelhuda ${ }^{1}$, Amal Bashir $^{2}$, Sarah ElKogali ${ }^{2}$, Muna Mustafa $^{2}$, Margaret Kruk $^{3}$ and Muna Abdel Aziz ${ }^{2}$

${ }^{1}$ Faculty of Dentistry, University of Khartoum, Khartoum, Sudan (Correspondence to: N.M. Nurelhuda: n.nurelhuda@gmail.com). ${ }^{2}$ Public Health Institute, Federal Ministry of Health, Khartoum, Sudan. ${ }^{3}$ Columbia University Mailman School of Public Health, New York, United States of America.

\begin{abstract}
Background: Out-migration of physicians and urban-rural maldistribution are two of the most serious challenges facing the health sector.
\end{abstract}

Aims: To determine the preference of junior doctors for rural postings in Sudan, and estimate how much junior doctors are willing to trade off from their salaries for nonmonetary incentives.

Methods: The study targeted junior doctors who had completed their internship training and were taking their Medical Licensing Examination at the Sudan Medical Council for permanent registration. Focus group discussions were conducted to identify potentially valued incentives. A computer-based discrete choice experiment and accompanying questionnaire were administered between September and October 2012 at the two licence examination centres in Sudan.

Results: Four hundred and fifty-five doctors completed the survey. More than one third of the respondents intended to emigrate from Sudan immediately and another $30 \%$ within the next two years. The findings showed that providing scholarships to train abroad, improving the standard of health facilities to an advanced level, and providing on-site supervision were the attributes most preferred by the respondents and they were willing to trade off SDG 3650 (US\$ 608), SDG 1997 (US\$333) and SDG 1948 (US\$325) of their salaries for these, respectively. Less-preferred attributes were availability of supervision by telephone, followed by a scholarship in family medicine and a 2-year commitment, post-training.

Conclusions: Authorities may consider the above preferences to enhance human resources for attraction strategies in rural areas. Addressing the supervision issue may be more feasible for policy-makers in the short term, when compared to improving salaries and infrastructure.

Keywords: junior doctors, Sudan, rural areas, migration, salary

Citation: Nurelhuda N; Bashir A; ElKogali S; Mustafa M; Kruk M; Abdel Aziz M. Encouraging junior doctors to work in rural Sudan: a discrete choice experiment. East Mediterr Health J. 2018;24(9):838-845. https://doi.org/10.26719/2018.24.9.838

Received: 23/04/18; accepted: 18/07/18

Copyright (c) World Health Organization (WHO) 2018. Some rights reserved. This work is available under the CC BY-NC-SA 3.o IGO license (https:// creativecommons.org/licenses/by-nc-sa/3.o/igo).

\section{Introduction}

The World Health Report of 2006 estimated that half of the global population was living in rural areas served by $<25 \%$ of the total number of physicians (1). This is often a serious impediment to ensuring equal access to basic health services and achieving health system goals (2).

Outmigration of physicians and urban-rural maldistribution are some of the most serious challenges facing the Sudanese health sector today. Over $60 \%$ of the 21000 physicians registered with Sudan Medical Council in 2005 have emigrated from Sudan (3). Almost three quarters $(70 \%)$ of those remaining in Sudan are working in major cities, with $64 \%$ in the capital, Khartoum (Sudan Federal Ministry of Health, personal communication, 2006).

The World Health Organization (WHO) recommendations on increasing access to health workers in rural and remote areas cover four main areas: education, regulation, financial incentives, and personal and professional support (4). These guidelines have been adopted in different settings but without systematic impact evaluation on workforce distribution.
Intervention packages adapted to local settings are more likely to be successful than uniform global approaches (5). Discrete choice experiments (DCEs) can help to identify the intervention packages best suited to the local context. DCEs are used to assess the stated preferences for goods, services or programmes as a function of their attributes $(6,7)$. An important strength of DCEs is that they can assess preference for aspects of programmes that have not yet been implemented $(6,8)$.

This study aimed to determine the preference of junior doctors for rural postings in Sudan, and to estimate how much they are willing to trade off from their salaries for nonmonetary incentives. Through this study, the first of its kind in Sudan, it should be possible to recommend policy options to support retention of physicians in rural postings.

\section{Methods}

\section{Study setting}

Medical graduates undergo supervised training for one year (houseman/ internship) in recognized hospitals in rural or urban settings, in addition to another year of 
civil service to qualify for the medical licensing examination regulated by the Sudan Medical Council. This entitles them to permanent registration at the Sudan Medical Council as physicians. The target population for this study, junior doctors, were physicians sitting the licensing examination at the only two medical licence examination centres in Sudan. These centres receive candidates from across the country, thus rendering them representative of junior doctors in Sudan.

\section{Development of DCE tool}

\section{Methods used to develop attributes}

Preferred job characteristics (attributes) were obtained through focus group discussions. Seven focus group discussions were run until saturation was reached. Each group comprised an average of six physicians/junior doctors, a facilitator, a note-taker and an observer. Proceedings were audiotaped and later transcribed verbatim. Nine attributes were listed and ranked by the physicians.

A Delphi exercise with $>$ five policy-makers at the Sudanese Ministry of Health was conducted over two rounds to reach consensus over the most relevant and feasible attributes. This was followed by a pilot study among junior doctors to estimate the utility of each attribute. This culminated in a discussion among the researchers and policy-makers resulting in the exclusion of three attributes that showed no significant utility. "Providing school allowances for employee's children" was possibly not valued because private schooling was not available in many rural areas. "Ensuring security in war-zone areas" was only an issue in a few areas, so it would have been irrelevant to the majority of physicians. "Providing postcontract loans to buy land" in rural areas was not of interest to physicians, and this attribute was dropped as it would be logistically difficult to arrange for land in Khartoum. "Housing" did not show statistically significant results; however, the authors chose to keep it since it was a common attribute in all published studies.

The final incentive packages to be used in the DCE included 6 attributes: quality of facility infrastructure; availability of clinical supervisors; salary; length of contract or commitment; scholarship for postgraduate training after completion of contract; and housing. For each attribute, levels were agreed with the policy-makers and physicians. The situation in Khartoum was the ideal reference, and the remaining levels reflected diverse rural situations. Table 1 shows the attributes and levels of the DCE. With regard to the scholarship attribute, policy-makers suggested the inclusion of a level specific to family medicine because there was interest at the Ministry to train family doctors.

\section{DCE questionnaire design}

The six attributes produced a full factorial design of 2304 possible alternatives (job postings). The attributes and levels were assorted into a policy-package module using Sawtooth software (9). Thirteen choice sets were selected for the DCE per participant using an experimental process that maximized level balance (inclusion of levels in similar proportions) and orthogonality (no correlation between levels of different attributes) and minimized

Table 1 Attributes and levels used in the DCE questionnaire (US\$ 1 = SDG 6)

\begin{tabular}{|c|c|}
\hline Attributes & Levels \\
\hline 1. Facility & $\begin{array}{l}\text { 1. Advanced - reliable electricity, available equipment, drugs, supplies, transport } \\
\text { 2. Basic - unreliable electricity, equipment, drugs and supplies transport and } \\
\text { medication not available }\end{array}$ \\
\hline 2. Availability of experienced clinical supervisor & $\begin{array}{l}\text { 1. Always on site } \\
\text { 2. Not always on site, but visits site regularly } \\
\text { 3. Not on site, reachable through phone only } \\
\text { 4. Not available }\end{array}$ \\
\hline 3. Monthly salary plus financial incentives in SDG & $\begin{array}{l}1.750 \\
2.1000 \\
3.1500 \\
4.2000 \\
5.3000 \\
6.4000 \\
7.5000 \\
8.6000\end{array}$ \\
\hline 4. Duration of commitment to work in health facility (years) & $\begin{array}{l}1.1 \\
2.2 \\
3.3\end{array}$ \\
\hline $\begin{array}{l}\text { 5. Guaranteed full scholarship for postgraduate training after } \\
\text { completion of contract }\end{array}$ & $\begin{array}{l}\text { 1. Inside Sudan } \\
\text { 2. Outside Sudan } \\
\text { 3. Family medicine training offered during the commitment years } \\
\text { 4. Not available }\end{array}$ \\
\hline 6. Housing & $\begin{array}{l}\text { 1. Housing allowance provided } \\
\text { 2. Governmental housing provided } \\
\text { 3. No allowance nor housing provided }\end{array}$ \\
\hline
\end{tabular}

$S D G=$ Sudanese pounds 
overlap among attribute levels within one task - this is known as an efficient design. Respondents were then asked to select their preferred job from each pair of 13 tasks (12 random and one fixed). Figure 1 shows a screen shot for a choice task, translated from Arabic.

The choice in this labelled DCE was between three job posts in a rural health centre, rural hospital, or urban hospital outside Khartoum. There was also an optional opt-out to stay in Khartoum. Participants were instructed to choose this option if they were not attracted by the job descriptions in the scenario. The accompanying survey included questions on demographic characteristics, educational background, international and rural experiences, and future career plans. The DCE and survey were piloted to assess the delivery in the examination setting, face validity and clarity of the tool. Ethical clearance was obtained from the Technical Ethical Committee in the Research Department, Federal Ministry of Health.

\section{Sampling frame}

All 570 candidates who took the permanent registration test from 1 September to 31 October 2012 were invited to participate (15.1\% of all physicians eligible to sit the examination in 2012).

\section{Data collection}

The DCE and associated survey were administered using computer-based, self-completed questionnaires (Table 1). Trained facilitators were available during the process. Before the examination started, the candidates were in- vited to participate in the study and given instructions on how to complete the questionnaire. Informed written consent was obtained. After conclusion of the three-hour examination, candidates who had consented undertook the DCE and survey using Sawtooth software.

\section{Statistical analysis}

Data were cleaned and transferred to Stata version 12. Bivariate analysis was done to test the association between career choices and future plans with individual characteristics. Mixed logit models were fitted to DCE data (Sawtooth Software SMRT version 4.18). All attribute variables were specified as random, except salary, which was fixed in all models. This was to ensure obtaining positive salary values consistent with preferences.

All attribute variables were coded as categorical dummy variables, except salary, which was specified as continuous in all models. Although Bech et al. in 2005 encouraged the use of effects coding in DCEs, there is no recent evidence showing that it is any better (10). All mixed logit models were fitted using Stata's mixlogit command, and were specified with 500 Halton draws. To understand how respondents' characteristics influenced job attribute preferences, models that included interactions between characteristics and job attributes were estimated. Subgroup analysis was also done among individuals with no immediate intention to migrate to assess whether this group had different preferences for postings than the group as a whole.

Willingness to pay, the maximum amount a person would be willing to pay, or the amount of compensation

Figure 1 Screenshot of the DCE choice task

If these were the only options available outside Khartoum state, which one would you choose? Click on the respective grey button.

\begin{tabular}{|c|c|c|c|c|}
\hline & Urban Hospital & Rural hospital & Rural health centre & Other \\
\hline $\begin{array}{l}\text { Facility } \\
\text { set-up }\end{array}$ & $\begin{array}{l}\text { Advanced - reliable } \\
\text { electricity, available } \\
\text { equipment, drugs, } \\
\text { supplies, transport }\end{array}$ & $\begin{array}{c}\text { Basic - Unreliable } \\
\text { electricity, equipment, } \\
\text { drugs and supplies } \\
\text { transport and medication } \\
\text { not available }\end{array}$ & $\begin{array}{c}\text { Basic-Unreliable electricity, } \\
\text { equipment, drugs and supplies } \\
\text { transport and medication not } \\
\text { available }\end{array}$ & \multirow{6}{*}{$\begin{array}{l}\text { I am not } \\
\text { interested in any } \\
\text { of the before } \\
\text { choices if they } \\
\text { are out of } \\
\text { Khartoum state. }\end{array}$} \\
\hline $\begin{array}{l}\text { Availability of } \\
\text { experienced clinical } \\
\text { supervisor }\end{array}$ & Always on site & $\begin{array}{l}\text { Not always on site, but } \\
\text { visits site regularly }\end{array}$ & $\begin{array}{l}\text { Not on site, reachable through } \\
\text { phone only }\end{array}$ & \\
\hline $\begin{array}{l}\text { Monthly Salary } \\
\text { plus financial } \\
\text { incentives in SDG }\end{array}$ & 750 & 1000 & 1000 & \\
\hline $\begin{array}{l}\text { Duration of } \\
\text { commitment to } \\
\text { work in health } \\
\text { facility (in years) }\end{array}$ & 1 & 1 & 3 & \\
\hline $\begin{array}{l}\text { Guaranteed full } \\
\text { scholarship for } \\
\text { postgraduate } \\
\text { training after } \\
\text { completion of } \\
\text { contract }\end{array}$ & Not available & Not available & Inside Sudan & \\
\hline Housing & $\begin{array}{l}\text { No allowance nor } \\
\text { housing provided }\end{array}$ & $\begin{array}{l}\text { Housing allowance } \\
\text { provided }\end{array}$ & $\begin{array}{l}\text { No allowance nor housing } \\
\text { provided }\end{array}$ & \\
\hline & 0 & & 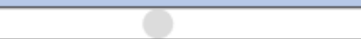 & \\
\hline
\end{tabular}


Figure 2 Willingness to pay among all junior doctors compared to those with no intention to migrate within the next two years

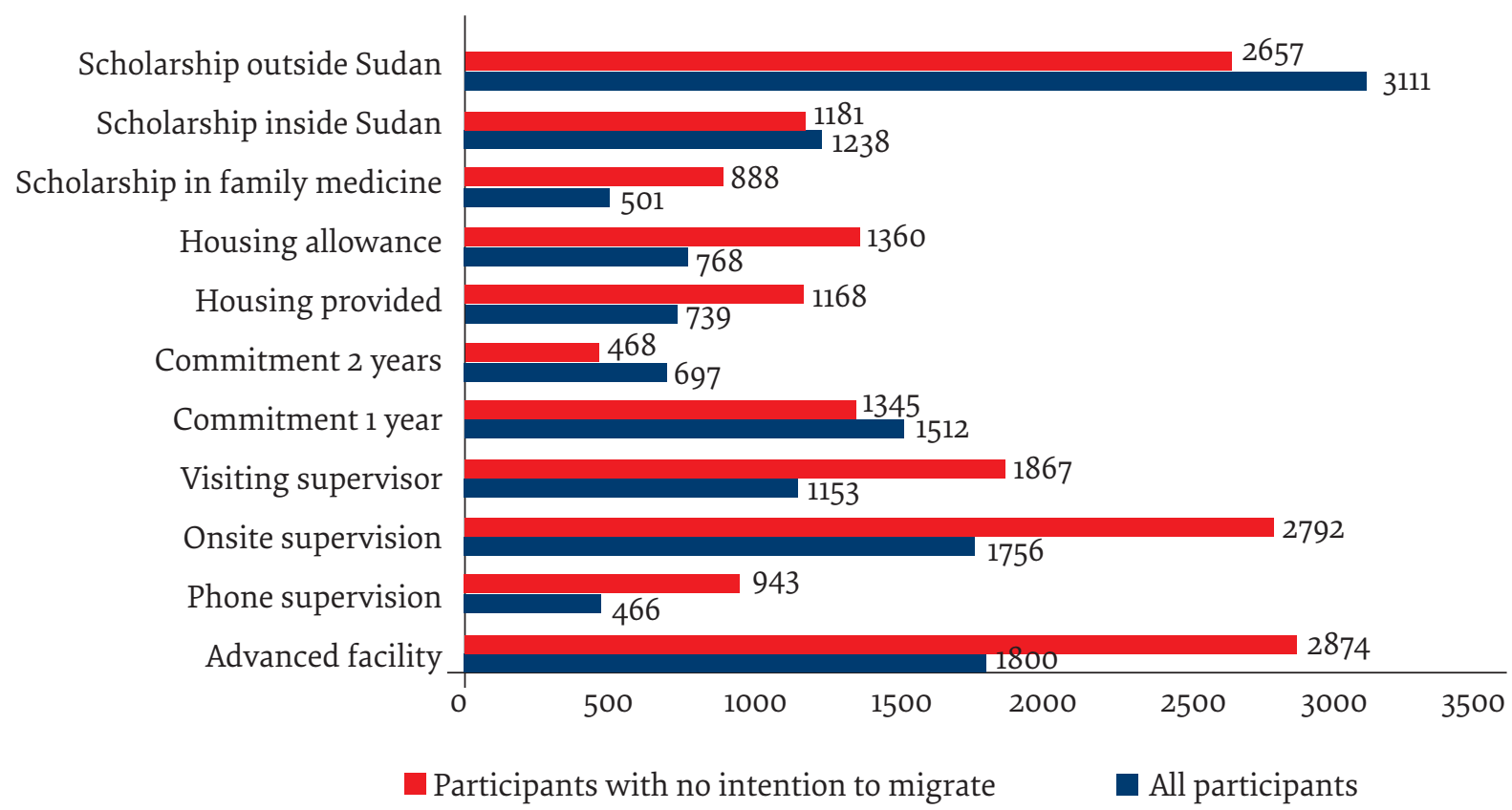

required to give up a unit change in an attribute, was estimated by dividing attribute coefficients by the salary coefficient for each model. Willingness to pay allowed for comparison of attribute utilities among subgroups.

\section{Results}

Out of 570 invited physicians, 455 agreed to participate (80\% response rate). The mean age of participants was 26 years (standard deviation 1.93, range 22-37 years). General characteristics of participants are shown in Table 2. More than two thirds of the study participants intended to migrate within two years. More graduates from universities based in Khartoum intended to migrate immediately or within 2 years compared to graduates from other universities, albeit a small difference ( $98 \%$ vs. $92 \%$ respectively, $\left.\chi^{2}=8.0984, P=0.004\right)$. There was no significant difference by gender $\left(\chi^{2}=0.5689, P=0.451\right)$.

\section{Preferences for job attributes}

The magnitude of the coefficients in Table 3 reflects the magnitude of preference or utility for each attribute against the baseline. All the coefficients were statistically significant, which indicates that the selected attributes were meaningful to respondents. Utilities for rural hospitals and health centres were negative, which showed lower preference for them compared to urban hospitals. Utility for opt-out was positive, which showed that, overall, physicians preferred to stay in Khartoum. Scholarship outside Sudan, advanced facility, on-site supervision and one-year commitment were the most preferred attributes. The least preferred were on-the-telephone supervision followed by a scholarship in family medicine and a two-year commitment to remain in post.

The interaction between women and on-site supervision $[\beta=0.50$; $95 \%$ confidence interval $(\mathrm{CI})=0.24$ $0.76]$ and women and on-the-telephone supervision $(\beta=$
$0.29 ; 95 \% \mathrm{CI}=0.03-0.56)$ was positive. The interaction was negative between women and scholarship training outside Sudan. The interaction among graduates from universities outside Khartoum, rural background and rural internship was not significant.

\section{Willingness to pay}

Providing scholarship training outside Sudan was the most valued attribute, and physicians were willing to sacrifice 3111 Sudanese pounds (SDG) (US\$ 519) in monthly salary for this (95\% CI = US\$ 439-598) (Figure 2). Improving the standards and equipment of health facilities to an advanced level and providing on-site supervision were the next preferred attributes, and physicians were willing to sacrifice SDG 1800 (US\$ 300) $(95 \% \mathrm{CI}=\mathrm{US} \$$ 232-368) and SDG 1756 (US\$ 293) (95\% CI = US\$ 224-361), respectively, from their salaries for these. This represents an amount much larger than their monthly salary, three times as much, thus demonstrating their eagerness for a supportive learning environment.

Compared with all respondents, those with no intention to migrate showed a greater preference for improved facility equipment and on-site supervision (Figure 2). They were willing to pay SDG 2874 (US\$ 479) and SDG 2792 (US\$ 465), respectively, for these, compared to SDG 1800 (US\$300) and SDG 1756 (US\$ 293) by all respondents. In contrast, the respondents with no intention to migrate had a lower preference for scholarship training outside Sudan, and were willing to pay SDG 2657 (US\$D 443) compared to SDG 3111 (US\$ 519) by all respondents.

\section{Discussion}

This study shows that the Sudanese health system is faced with a major challenge; namely, that more than two thirds of the study participants intended to emi- 


\begin{tabular}{|c|c|c|}
\hline Characteristics & $\mathbf{n}$ & $\%$ \\
\hline \multicolumn{3}{|l|}{ Sex } \\
\hline Male & 189 & 41.8 \\
\hline Female & 263 & 58.2 \\
\hline \multicolumn{3}{|l|}{ Marital status } \\
\hline Single & 316 & 69.9 \\
\hline Engaged & 60 & 13.3 \\
\hline Divorced & 1 & 0.2 \\
\hline Married & 75 & 16.6 \\
\hline \multicolumn{3}{|l|}{ Having children } \\
\hline Yes & 43 & 9.5 \\
\hline No & 408 & 90.5 \\
\hline \multicolumn{3}{|l|}{ Grown up in Sudan } \\
\hline Yes & 301 & 66.7 \\
\hline No & 150 & 33.3 \\
\hline \multicolumn{3}{|l|}{ Area of growing up } \\
\hline Urban & 372 & 82.5 \\
\hline Rural & 79 & 17.5 \\
\hline \multicolumn{3}{|l|}{ Internship place } \\
\hline Sudan & 447 & 99.33 \\
\hline Outside & 3 & 0.67 \\
\hline \multicolumn{3}{|l|}{ Internship in rural areas } \\
\hline Yes & 108 & 24.2 \\
\hline No & 339 & 75.8 \\
\hline \multicolumn{3}{|c|}{ Preference for working in home state } \\
\hline Yes & 233 & 51.8 \\
\hline No & 217 & 48.2 \\
\hline \multicolumn{3}{|l|}{ Intention to migrate } \\
\hline Yes, immediately & 161 & 35.78 \\
\hline Yes, within two years & 132 & 29.33 \\
\hline Yes, after specialization & 57 & 12.67 \\
\hline Never & 13 & 2.89 \\
\hline Don't know & 87 & 19.33 \\
\hline
\end{tabular}

grate within two years. Even some of those who were not thinking of emigrating any time soon ( $\mathrm{n}=157,35 \%)$ had an intention to do so after their specialization ( $\mathrm{n}=57$, $36 \%$ ). This reflects a significant level of attrition and creates an important context when interpreting the results. All participants expressed a high preference for scholarships to train abroad, followed by improvement of health facility standards and provision of on-site supervision. Those with no intention to migrate showed a greater preference for improvement of health facility standards and on-site supervision, followed by training abroad. Surprisingly, both genders had similar intentions to migrate. Sociocultural issues such as spouse and family considerations can play a role in women's decisions. This may have implications that need to be addressed in view of the growing feminization of the health profession in Sudan (Sudan Federal Ministry of Health, personal communica- tion, 2006). In the United Republic of Tanzania, women are less responsive to pecuniary incentives and more concerned with factors that directly allow them to do a good job (11).

Sudanese junior doctors valued salary increase. In Thailand, physicians from rural backgrounds were more sensitive than others to a $45 \%$ salary increase. In Ethiopia, physicians were more responsive than nurses to salary increases (12), while a study of medical students in Ghana showed that a 50\% salary increase was almost as highly valued as free superior housing or a utility car (6). This suggests that preferences for salary increases are highly context dependent. In Sudan, health-worker salaries are low by comparison to North Africa and even to poorer countries in sub-Saharan Africa. At the time of this study junior doctors in Sudan earned on average SDG 600 (US\$100) per month. There is large variation in salaries as top-ups are routinely instituted to attract physicians and nurses to states outside Khartoum. These top-ups can amount to three to five or more times the basic salary depending on the rural zone. The current economic crisis in Sudan makes it unlikely that policymakers can consider competitive salary increases to retain physicians, making this attribute not amenable for policy reform.

The most valued attribute by all participants was obtaining a scholarship for training outside Sudan. Current evidence also supports the implementation of well-defined education policies to redress the inequitable distribution of healthcare professionals to rural areas $(6,13)$. Scholarship training in family medicine in Sudan was one of the least preferred attributes, even among those with no plans to migrate.

Physicians valued on-site clinical supervision. Lack of supervision may be perceived by physicians as hindering skills and career development and may be an important barrier to rural recruitment. Facility equipment also emerged as an important attribute. It included consistent availability of medicines, water and electricity, especially in health centres. This was similar to findings from the United Republic of Tanzania, where offers of good housing and infrastructure, including provision of equipment, increased recruitment to rural areas, although not as much as higher wages and education did (11). During the focus group discussions, physicians expressed concern that their skills would not be of use without appropriate equipment. In larger hospitals, the concern was about inadequate or nonexistent diagnostic equipment, laboratories and other technology. The importance of equipment also emerged from other DCEs $(6,11,14,15)$.

A brief one-year commitment to rural areas was preferable to longer postings. In contrast, state health system and hospital managers complained that postings $<3$ years are undesirable due to the frequent turnover and loss of experienced physicians. Unlike other DCEs $(6,11,14)$, housing was not detected as an important predictor for job selection, which confirmed the original pilot findings. 


\begin{tabular}{|c|c|c|c|c|}
\hline Attribute & Coefficient & $95 \% \mathrm{CI}$ & SD & SE \\
\hline \multicolumn{5}{|c|}{ Choices label (\% of respondents who selected the option) } \\
\hline Urban hospital outside Khartoum (33.19) & \multicolumn{4}{|c|}{ Reference } \\
\hline Rural health centre (22.37) & $-0.71^{* *}$ & -0.81 to -0.60 & & 0.05 \\
\hline Rural hospital (29.96) & $-0.22^{* *}$ & -0.81 to -0.60 & & 0.05 \\
\hline Opt-out (14.48) & $1.55^{* *}$ & $1.29-1.82$ & & 0.10 \\
\hline Salary of SDG 1000 & $0.33^{* *}$ & $0.24-0.32$ & & 0 \\
\hline \multicolumn{5}{|l|}{ Facility equipment } \\
\hline Basic facility & \multicolumn{4}{|c|}{ Reference } \\
\hline Advanced facility & $0.60^{* *}$ & $0.46-0.73$ & 1.16 & 0.07 \\
\hline \multicolumn{5}{|l|}{ Clinical supervision } \\
\hline No supervisor & \multicolumn{4}{|c|}{ Reference } \\
\hline Visiting supervisor & $0.38^{* *}$ & $0.26-0.51$ & 0.57 & 0.07 \\
\hline On-site supervisor & $0.58^{* *}$ & $0.45-0.72$ & 0.78 & 0.07 \\
\hline Telephone supervisor & $0.16^{*}$ & $0.02-0.29$ & 0.68 & 0.07 \\
\hline \multicolumn{5}{|l|}{ Years of commitment } \\
\hline 3 & \multicolumn{4}{|c|}{ Reference } \\
\hline 1 & $0.50^{* *}$ & $0.38-0.63$ & 0.93 & 0.07 \\
\hline 2 & $0.23^{* *}$ & $0.13-0.34$ & 0.42 & 0.05 \\
\hline \multicolumn{5}{|l|}{ Housing } \\
\hline No housing & \multicolumn{4}{|c|}{ Reference } \\
\hline Housing provided & $0.25^{* *}$ & $0.14-0.35$ & 0.50 & 0.05 \\
\hline Housing allowance & $0.26^{* *}$ & $0.14-0.37$ & 0.58 & 0.06 \\
\hline \multicolumn{5}{|l|}{ Scholarship for training } \\
\hline No scholarship & \multicolumn{4}{|c|}{ Reference } \\
\hline Scholarship outside Sudan & $1.04^{* *}$ & $0.88-1.19$ & 1.15 & 0.08 \\
\hline Scholarship inside Sudan & $0.41^{* *}$ & $0.28-0.55$ & 0.66 & 0.07 \\
\hline Scholarship in family medicine & $0.17^{*}$ & $0.02-0.31$ & 0.79 & 0.07 \\
\hline
\end{tabular}

The strengths of this study included the systematic qualitative methodology by which the attributes were developed. The consensus meeting with decision-makers helped to engage policy-makers and gain interest and ownership for research results. The use of labelled choices was another strength, which allowed for assessment of preferences specific to different job situations. This also allowed for more flexibility in the definition of the scenarios proposed and thus made the DCE more policy relevant (16).

The study had some limitations. DCEs use brief descriptions of complex attributes. This could affect the external validity of the study because of the possible variation in the interpretation of attributes (8). Producing nationally representative data would require larger samples, complex sampling strategies and more resources. However, the sampling technique in this study was sound enough to serve the purpose and the study was sufficiently powered to detect significant findings from the overall coverage of the September/October examination sittings. Generalization of the study may be limited in other countries where financial remuneration is more generous than in Sudan, and indeed this has contributed to the push and pull for physicians intending to emigrate. Although the context varies, we believe that countries in the Middle East and North Africa and WHO Africa Region can benefit from the attributes of the study that can be explored with local junior doctors and tested to inform human resources for health policy. Staffing of public sector health facilities in remote rural areas is a challenge for many ministries of health. There is no strong evidence of interventions addressing the inequitable distribution of healthcare professionals within low-andmiddle-income countries, or interventions to reduce migration of healthcare professionals from them (17-20). This is further complicated by lack of knowledge about what is the best mix in a bundle of interventions.

What is now needed is more research and further evidence regarding long-term sustainability of a suite of interventions to attract and retain staff in remote areas (21). This DCE should be followed by studies that present the preferred package to the target population, 
and the uptake of these packages by new graduates should be assessed prospectively. In particular, posting more experienced clinicians to health centres outside Khartoum may be an important draw for physicians.

\section{Conclusions}

Sudanese doctors are willing to trade-off substantial parts of their salary for nonmonetary incentives and may consider rural posts if they were made attractive. Author- ities may consider improving training, health facility standards and supervision to enhance human resources for health attraction strategies. Addressing the supervision issue may be more feasible for policy-makers in the short term, when compared to improving infrastructure, from a cost perspective.

Funding: None.

Conflicts of interest: None declared.

\section{Encourager les jeunes médecins à travailler en zones rurales au Soudan : une expérience en choix discret}

\section{Résumé}

Contexte : L'exode des médecins et la répartition déséquilibrée entre zones urbaines et rurales comptent actuellement parmi les difficultés les plus importantes auxquelles se voit confronté le secteur de la santé.

Objectifs : Déterminer le degré de préférence des jeunes médecins en faveur de postes en zones rurales au Soudan et estimer à quel point ils sont prêts à échanger une partie de leurs salaires contre des incitations non monétaires.

Méthodes : L'étude a ciblé des jeunes médecins ayant terminé leur internat et se préparant à l'examen d'homologation en tant que médecin auprès du Conseil des médecins du Soudan afin d'obtenir leur inscription définitive. Des discussions ont été menées en groupes de travail afin de définir des incitations dont la valeur serait susceptible d'être reconnue. Une méthode d'expérimentation des choix, discrète, informatisée et accompagnée d'un questionnaire a été appliquée entre septembre et octobre 2012 dans les deux centres d'examen d'homologation soudanais.

Résultats : Quatre cent cinquante - cinq médecins ont terminé l'enquête. Plus d'un tiers des répondants a déclaré avoir l'intention de quitter immédiatement le Soudan et $30 \%$ de plus prévoyaient de le faire dans les deux années suivantes. Les conclusions ont montré que l'attribution de bourses de formation à l'étranger, l'amélioration des normes des établissements de santé afin d'atteindre un niveau avancé et le contrôle par un médecin responsable sur place constituaient les avantages les plus cités par les répondants ; ces derniers se sont également déclarés prêts à échanger, respectivement, SDG 3650 (608 dollars des États - Unis [USD]), SDG 1997 (USD 333) et SDG 1948 (USD 325) de leurs salaires pour bénéficier de ces avantages. Les avantages les moins populaires étaient les suivants : disponibilité du médecin responsable au téléphone, suivi par une bourse d'étude en médecine générale et engagement de deux ans après la formation.

Conclusions : Les autorités pourraient envisager de tenir compte des choix préférentiels décrits ci-dessus afin de valoriser les stratégies d'attraction vers les zones rurales auprès des ressources humaines. À court terme, les décideurs politiques pourraient éprouver moins de difficultés à traiter le problème du contrôle par des médecins responsables que celui de l'amélioration des salaires et des infrastructures.

$$
\begin{aligned}
& \text { تشجيع الأطباء حديثي التخرج على العمل في الأرياف في السودان: تجربة اختيار منفصلة }
\end{aligned}
$$

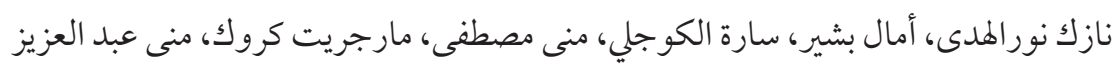

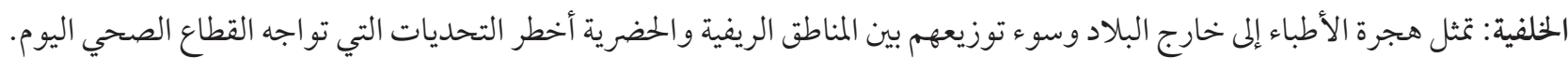

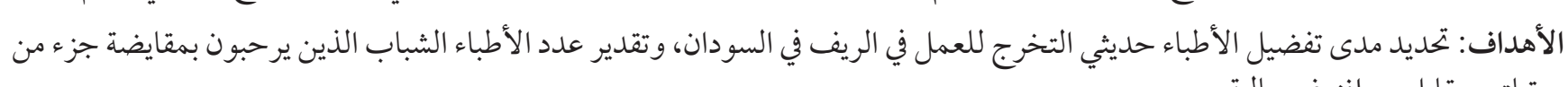

$$
\begin{aligned}
& \text { مر تباتهم مقابل حو افز غير مالير مالية. }
\end{aligned}
$$

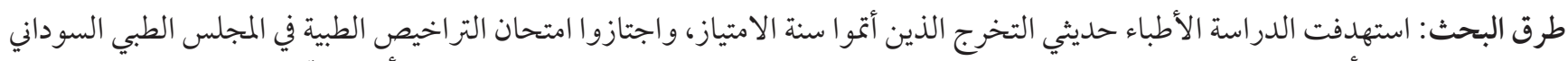

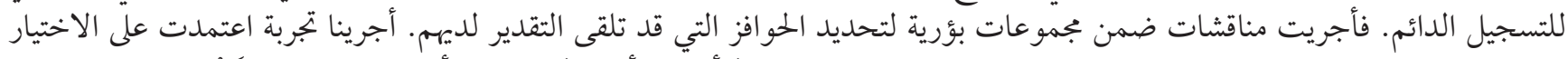

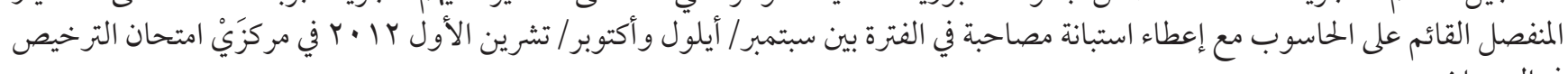

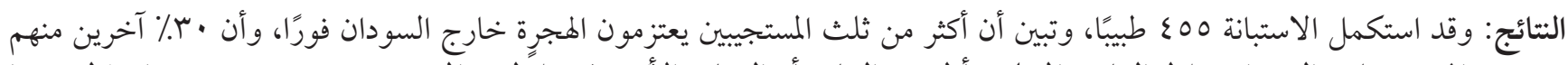

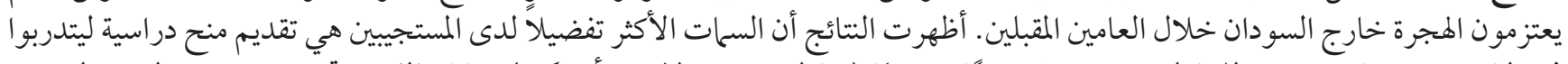

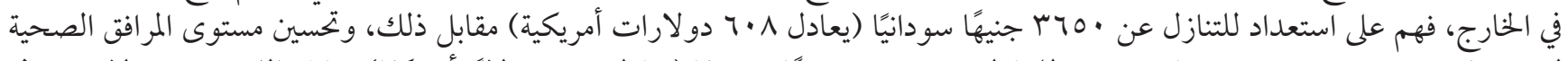

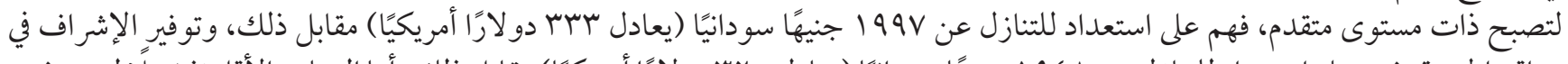

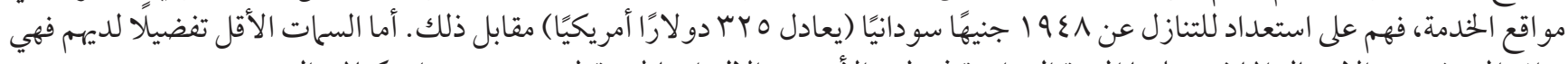

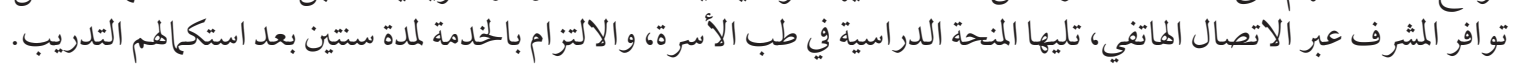




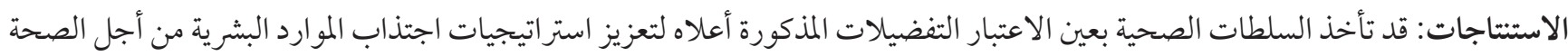

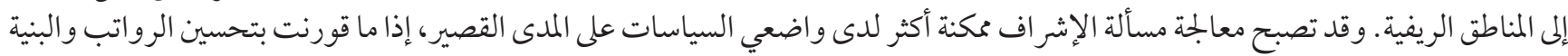

\section{References}

1. Monitoring the geographical distribution of the health workforce in rural and underserved areas. Spotlight on Health Workforce Statistics. Issue 8, October 2009 (http://www.who.int/hrh/statistics/spotlight_8_en.pdf, accessed 26 July 2018).

2. Travis P, Bennett S, Haines A, Pang T, Bhutta Z, Hyder AA, et al. Overcoming health-systems constraints to achieve the Millennium Development Goals. Lancet. 2004 Sep 4-10;364(9437):900-6. https://doi.org/10.1016/So140-6736(04)16987-0 PMID:15351199

3. Badr E. Brain drain of health professionals in Sudan: magnitude, challenges and prospects for solution [thesis]. University of Leeds; 2005.

4. Increasing access to health workers in remote and rural areas through improved retention: global policy recommendations. Geneva: World Health Organization; 2010 (http://whqlibdoc.who.int/publications/2010/9789241564014_eng.pdf?ua=1, accessed 26 July 2018)

5. Blaauw D, Erasmus E, Pagaiya N, Tangcharoensathein V, Mullei K, Mudhune S, et al. Policy interventions that attract nurses to rural areas: a multicountry discrete choice experiment. Bull World Health Organ. 2010 May;88(5):350-6. https://doi.org/10.2471/ BLT.09.072918 PMID:20461141

6. Kruk ME, Johnson JC, Gyakobo M, Agyei-Baffour P, Asabir K, Kotha SR, et al. Rural practice preferences among medical students in Ghana: a discrete choice experiment. Bull World Health Organ. 2010 May;88(5):333-41. https://doi.org/10.2471/BLT.09.072892 PMID:20458371

7. Lancsar E, Louviere J. Conducting discrete choice experiments to inform healthcare decision making: a user's guide. Pharmacoeconomics. 2008;26(8):661-77. https://doi.org/10.2165/00019053-200826080-00004 PMID:18620460

8. Mandeville KL, Lagarde M, Hanson K. The use of discrete choice experiments to inform health workforce policy: a systematic review. BMC Health Serv Res. 2014 Sep 1;14:367. https://doi.org/10.1186/1472-6963-14-367 PMID:25179422

9. Hole AR, Kolstad JR. Mixed logit estimation of willingness to pay distributions: a comparison of models in preference and WTP space using data from a health-related choice experiment. Empir Econ. 2012 4;42(2):445-69. https://doi.org/10.1007/s00181-0110500-1

10. Bech M, Gyrd-Hansen D. Effects coding in discrete choice experiments. Health Econ. 2005 Oct;14(10):1079-83. https://doi. org/10.1002/hec.984 PMID:15852455

11. Louviere J, Hensher D, Swait J. Stated choice methods: analysis and applications. Cambridge: Cambridge University Press; 2000. https://doi.org/10.1017/CBO9780511753831

12. Hanson K, Jack W. Health worker preferences for job attributes in Ethiopia: results from a discrete choice experiment. Health Systems for Outcomes Publication; 2008 (http://documents.worldbank.org/curated/en/716191468030240068/pdf/531220WPoHealt1oBox345596Bo1PUBLIC1.pdf, accessed 26 July 2018).

13. Wilson NW, Couper ID, De Vries E, Reid S, Fish T, Marais BJ. A critical review of interventions to redress the inequitable distribution of healthcare professionals to rural and remote areas. Rural Remote Health. 2009 Apr-Jun;9(2):1060. PMID:19530891

14. Rockers PC, Jaskiewicz W, Wurts L, Kruk ME, Mgomella GS, Ntalazi F, et al. Preferences for working in rural clinics among trainee health professionals in Uganda: a discrete choice experiment. BMC Health Serv Res. 2012 Jul 23;12(1):212. https://doi. org/10.1186/1472-6963-12-212 PMID:22824497

15. George G, Gow J, Bachoo S. Understanding the factors influencing health-worker employment decisions in South Africa. Hum Resour Health. 2013 Apr 23;11(15):15. https://doi.org/10.1186/1478-4491-11-15 PMID:23618349

16. Lagarde M, Pagaiya N, Tangcharoensathian V, Blaauw D. One size does not fit all: investigating doctors' stated preference heterogeneity for job incentives to inform policy in Thailand. Health Econ. 2013 Dec;22(12):1452-69. https://doi.org/10.1002/hec.2897 PMID:23349119

17. Lagarde M, Blaauw D, Cairns J. Cost-effectiveness analysis of human resources policy interventions to address the shortage of nurses in rural South Africa. Soc Sci Med. 2012 Sep;75(5):801-6. https://doi.org/10.1016/j.socscimed.2012.05.005 PMID:22687725

18. Grobler L, Marais BJ, Mabunda S, Marindi PN, Reuter H, Volmink J. Interventions for increasing the proportion of health professionals practising in rural and other underserved areas. Cochrane Database Syst Rev. 2015 Jun 30; (6):CDoo5314. 10.1002/14651858. CDoo5314.pub3 PMID:26123126

19. 19. Peñaloza B, Pantoja T, Bastías G, Herrera C, Rada G. Interventions to reduce emigration of health care professionals from low- and middle-income countries. Cochrane Database Syst Rev. 2011 Sep 7; (9):CDoo7673. 10.1002/14651858.CDoo7673.pub2 PMID:21901709

20. Chopra M, Munro S, Lavis JN, Vist G, Bennett S. Effects of policy options for human resources for health: an analysis of systematic reviews. Lancet. 2008 Feb 23;371(9613):668-74. https://doi.org/10.1016/S0140-6736(08)60305-0 PMID:18295024

21. Abuagla A, Badr E. Challenges to implementation of the WHO Global Code of Practice on International Recruitment of Health Personnel: the case of Sudan. Hum Resour Health. 201606 30;14(S1):26. https://doi.org/10.1186/s12960-016-0117-8 PMID:27381022 